\title{
Influence of seven immunostimulants on the immune response of coho salmon to Aeromonas salmonicida
}

\author{
L. Nikl ${ }^{1}$, L. J. Albright ${ }^{1}$, T. P. T. Evelyn ${ }^{2}$ \\ ${ }^{1}$ Department of Biological Sciences, Simon Fraser University, Burnaby, B.C., Canada V5A 1S6 \\ ${ }^{2}$ Pacific Biological Station, Nanaimo, B.C., Canada V9R 5K6
}

\begin{abstract}
A study was conducted to evaluate the efficacy of 7 substances at potentiating a formalinkilled Aeromonas salmonicida bacterin in juvenile coho salmon Oncorhynchus kisutch. The substances were injected into the fish along with the bacterin. The fish were challenged $27 \mathrm{~d}$ later with viable $A$. salmonicida cells by 2 methods (cohabitation and immersion). The cumulative mortalities in each of the experimental groups was then determined. A significant and consistent increase in protection over the groups receiving only the $A$. salmonicida bacterin was observed with 3 of the substances tested. These were VitaStim-Taito, lentinan and formalin-killed Renibacterium salmoninarum cells. One of these materials, VitaStim-Taito (a $\beta-1,3$ glucan), showed particular promise for further studies.
\end{abstract}

\section{INTRODUCTION}

The first documented attempt to develop a vaccine for disease prevention in fish dates back to the furunculosis vaccination trials of Duff (1942). To date, however, and despite considerable subsequent research on the topic and the existence of commercially marketed anti-furunculosis vaccines (Ellis 1988), heavy losses of cultured salmonids due to furunculosis continue to occur. Chemotherapy is therefore frequently used to control the disease - an approach that is expensive, provides only short term benefit, and risks generating drug-resistant strains of the causative bacterium, Aeromonas salmonicida. These shortcomings, combined with a strong popular sentiment against the use of antibiotics in food fish continue to make the development of an effective furunculosis vaccine highly desirable.

Although the development of humoral immune factors specific for Aeromonas salmonicida is a typical response to exposure to the pathogen, the presence of these factors (antibodies) is not necessarily associated with protection (Michel 1979, Cipriano 1982, 1983, Olivier et al. 1985b). Smith et al. (1980) showed that immunity to furunculosis was more closely associated with the cellular components of the immune system than with the humoral ones. It is conceivable that furunculosis vaccination attempts might benefit from vaccines specifically designed to take advantage of the cell-mediated host defences.

One way to design a vaccine that will exploit the cellular immune response is to modify the antigenic determinants so that they preferentially stimulate cellular immunity. This approach was applied to sheep red blood cells (Parish 1972) and to bovine serum albumin (Coon \& Hunter 1973). However, such modifications applied to formalin-killed Aeromonas salmonicida cells met with little success in our studies (unpubl. own obs.). Another approach is to include an immunostimulant in the vaccine (Allison \& Byers 1986, Panangala et al. 1986). By combining an antigen with an immunostimulant, enhanced protection may be obtained, apparently through a more complete exploitation of the host's immune system.

Olivier et al. (1985a) were the first to demonstrate in salmon that the efficacy of an injected Aeromonas salmonicida vaccine could be increased by including a preparation (killed Mycobacterium butyricum cells) known to enhance cellular immunity. Similar results were found with other substances. Davis \& Hayasaka (1984) reported that an extract (EtE) from the tunicate Ecteinascidia turbinata potentiated the immune response of the American eel Anguilla rostrata to the pathogen A. hydrophila. Kitao \& Yoshida (1986) enhanced the non-specific resistance of rainbow trout Oncorhynchus mykiss to $A$. salmonicida with a synthe- 
tic peptide, administered without the antigen. The efficacy of levamisole as an immunostimulant is also under active investigation (Kajita et al. 1990, Siwicki et al. 1990). Finally, Yano et al. (1989) and Robertsen et al (1990) reported success at enhancing non-specific immunity against various bacterial fish pathogens ( $A$. hydrophila, Vibrio anguillarum, V. salmonicida, Yersinia ruckerl) with glucans derived from Schizophyllum commune and Saccharomyces cerevisiae, respectively.

In the present study, 7 substances, reported to enhance the cellular portion of the immune response in various animals, were tested to determine whether they could be used to potentiate the efficacy of an Aeromonas salmonicida vaccine. This paper reports on our findings with these materials.

\section{MATERIALS AND METHODS}

Experimental animals. Juvenile coho salmon Oncorhynchus kisutch used in these tests averaged $10.8 \mathrm{~g}$ (Experiment 1) and $22.5 \mathrm{~g}$ (Expt 2). The fish were raised in pathogen-free well water at the nearby Department of Fisheries and Oceans Rosewall Creek Hatchery. At least 2 wk prior to the start of each experiment, the fish were transferred to the laboratory where they were acclimated to ambient water temperatures over a period of several days $\left(1^{\circ} \mathrm{C} \mathrm{d} \mathrm{d}^{-1}\right)$. During handling for the purpose of injecting and fin-clipping, fish were anaesthetized with 2-phenoxyethanol $(1: 7000)$.

Immunostimulants. The immunostimulants used in this study were obtained from several sources. VitaStim-Taito (VST) was donated by Taito Co., Ltd (Tokyo, Japan). The product used in this study was a highly purified and partially depolymerized product with a molecular weight of $4.75 \times 10^{5}$. Lentinan was supplied by Ajinomoto Pharmaceutical Co., Ltd. (Tokyo, Japan). Wy-18,251 was supplied by Wyeth Laboratories, USA. Levamisole and diethyl-dithiocarbamate (DTC) were purchased from Sigma (St. Louis, MO). Modified Freund's complete adjuvant (MFCA) was prepared according to the methods of Olivier et al. (1985a). The Mycobacterium butyricum used in the preparation was a killed and dried product purchased from Difco (Detroit, MI, USA).

Renibacterium salmoninarum cells used to make the R. salmoninarum bacterin (RSB) were grown on KDM-2 agar (Evelyn 1977 ) at $15^{\circ} \mathrm{C}$ for $20 \mathrm{~d}$. The cells were harvested, suspended in $0.5 \%$ formal-saline overnight at room temperature, and washed 3 times in sterile saline $(0.85 \%)$. The suspension was kept refrigerated until use (within $1 \mathrm{wk}$ ).

Bacterin production. Aeromonas salmonicida (strain 76-30; Olivier et al. 1985a) was grown on trypticase soy agar (TSA, Difco) at $15^{\circ} \mathrm{C}$ for $5 \mathrm{~d}$, after which the cells were scraped from the agar using a glass rod and resuspended in $0.85 \%$ saline containing $0.5 \%$ formalin. This suspension was left overnight at room temperature. The bacterium was an autoaggregating isolate and its virulence was maintained by passage through coho salmon.

Vaccine preparation. Formalin-killed Aeromonas salmonicida cells (= bacterin) were combined with the immunostimulating agents (Table 1) and emulsified in modified Freund's incomplete adjuvant (MFIA) using a mortar and pestle as per Olivier et al. (1985a). The vaccines were compounded such that each fish received a $0.1 \mathrm{ml}$ injection containing $1 \mathrm{mg}$ of bacterin and the immunostimulant or saline at the dosage stated in Table 1.

Experimental design. For each treatment, there were 2 replicates. Each replicate consisted of 25 fish, each of which received a single intraperitoneal (i.p.) injection of the test vaccine. Control groups were injected with the bacterin emulsified in MFIA only. The fish within a given treatment were identified with fin clips unique for that particular treatment. Replicates of the combined treatment groups were held in separate flowthrough $650 \mathrm{l}$ aquaria where they were maintained at $13^{\circ} \mathrm{C} \pm 1 \mathrm{C}^{\circ}$ and fed a commercial dry diet ad libitum throughout the study.

The fish (mean weight $=10.8 \mathrm{~g}$ ) were vaccinated on August 11, 1987. Twenty-seven days post-vaccination, each of the replicates was challenged as described below. Replicate 1 was challenged by a 15 min immersion in $4.6 \times 10^{5}$ cells $\mathrm{ml}^{-1}$ of the pathogen. The challenge suspension was prepared using $4 \mathrm{~d}$ old Aeromonas salmonicida cells grown on TSA at $15^{\circ} \mathrm{C}$. Replicate 2 was challenged using a cohabitation procedure. In this procedure, 3 groups of 5 fish each were used as an 'infection source'. Fish in these groups were

Table 1 Candidate immunostimulant compounds

\begin{tabular}{|llr}
\hline Compound & Reference & Dose used \\
\hline VitaStim-Taito & Komatsu (1974) & $15 \mathrm{mg} \mathrm{kg}^{-1}$ \\
Lentinan & Hamuro et al. (1974) & $5 \mathrm{mg} \mathrm{kg}$ \\
Modified Freund's & Olivier et al. (1985a) & $5 \mathrm{mg} \cdot \mathrm{kg}^{-1}$ \\
Complete Adjuvant & & \\
$\begin{array}{l}\text { Diethyldi- } \\
\text { thiocarbamate }\end{array}$ & $\begin{array}{l}\text { Renoux \& Renoux } \\
\text { (1984) }\end{array}$ & $12.5 \mathrm{mg} \mathrm{kg}$ \\
R. salmoninarum & Amend \& Johnson & $92.6 \mathrm{mg} \mathrm{kg}^{-1}$ \\
bacterin & (1984) & \\
WY-18,251 & Gregory (1984) & $10 \mathrm{mg} \mathrm{kg}^{-1}$ \\
Levamisole & Amery \& Horig & $5 \mathrm{mg} \mathrm{kg}^{-1}$ \\
& (1984) & \\
Dose refers to the dried cells of Mycobacterium buty- \\
ricum present in the adjuvant emulsion administered
\end{tabular}


injected i.p. with 50, 500 or 5000 cells of the pathogen per fish. These fish were operculum-clipped for identification and added to the tank of vaccinated fish. By using 3 levels of challenge in the 'infection source' fish, a prolonged exposure to 'natural' levels of the pathogen was achieved.

Mortalities resulting from the challenge were monitored for $20 \mathrm{~d}$ in the immersion-challenged replicate and for $36 \mathrm{~d}$ in the cohabitation-challenged replicate. The monitoring periods differed because of the pattern of the mortality responses resulting from the 2 challenge methods.

Some $10 \%$ of the mortalities were selected at random so that cause of death could be verified. Furunculosis was considered to be the cause of death when short, Gram-negative, rod-shaped bacteria with slightly polar staining characteristics were evident in Gram-stained kidney smears, when pure cultures of the pigment-producing bacterium were recovered on TSA from the kidney samples, and when clinical signs in the dead fish were compatible with those caused by Aeromonas salmonicida.

Antibody titres. In Experiment 2, coho salmon were vaccinated with $0.1 \mathrm{ml}$ of an emulsion (MFIA) containing the bacterin and either VitaStim-Taito (VST), Lentinan or killed Renibacterium salmoninarum cells. Control groups received $0.1 \mathrm{ml}$ of the bacterin alone in MFIA or MFIA without bacterin.

The variously treated fish (10 fish group ${ }^{-1}$ ) were placed in a $135 \mathrm{l}$ flow-through aquarium and held at $13^{\circ} \mathrm{C} \pm 0.5 \mathrm{C}^{\circ}$ for $25 \mathrm{~d}$ until blood collection. Fin clips were used to denote the various treatments. Caudal blood was collected into $370 \mu \mathrm{l}$ heparinized capillary tubes (Fisher) and centrifuged at $11700 \mathrm{rpm}$ for $3 \mathrm{~min}$ in an Autocrit II (VWR Scientific) centrifuge. Resulting plasma was stored at $-20^{\circ} \mathrm{C}$ until it was assayed for agglutinin titre. A non-autoaggregating variant of isolate 76-30, obtained by culturing the bacterium several times on TSA at room temperature, was used as the antigen in the agglutinin assays. The agglutinin titre was determined using standard microtitre techniques in a 96 well microtitre plate.

Statistical analysis. Mortality data were analyzed for statistical significance using Fischer's exact test. Analysis of antibody titre data was done with the Student's $t$ test. The various statistical analyses are described in Zar (1984).

\section{RESULTS}

Results of the trials dealing with the various immunostimulants are summarized in Table 2; they indicate that 3 of the 7 immunostimulants tested (VST, lentinan, RSB) improved survival, irrespective of the challenge method used. In the treatment groups
Table 2. Oncorhynchus kisutch. Survival of variously vaccinated juvenile following challenge with Aeromonas salmonicida: the effect of using various immunostimulants in combination with an $A$. salmonicida bacterin

\begin{tabular}{|c|c|c|c|c|}
\hline $\begin{array}{l}\text { Challenge } \\
\text { type }\end{array}$ & $\begin{array}{l}\text { Treatment } \\
\text { rec } \mathrm{d}^{1}\end{array}$ & $\begin{array}{l}\text { \#Dead/ } \\
\text { \#tested }\end{array}$ & $\begin{array}{l}\% \\
\text { Mort }\end{array}$ & $p<0.05^{2}$ \\
\hline Immersion & $\begin{array}{l}\text { MFCA } \\
\text { VST } \\
\text { Lentinan } \\
\text { Levamisole } \\
\text { DTC } \\
\text { RSB } \\
\text { WY-18251 } \\
\text { Control }\end{array}$ & $\begin{array}{r}19 / 25 \\
18 / 28 \\
16 / 25 \\
21 / 25 \\
17 / 25 \\
9 / 25 \\
23 / 25 \\
24 / 25\end{array}$ & $\begin{array}{l}76 \\
64 \\
64 \\
84 \\
68 \\
36 \\
92 \\
96\end{array}$ & $\begin{array}{l}\mathrm{Y} \\
\mathrm{Y} \\
\mathrm{X} \\
\mathrm{N} \\
\mathrm{Y} \\
\mathrm{Y} \\
\mathrm{N} \\
-\end{array}$ \\
\hline Cohabitation & $\begin{array}{l}\text { MFCA } \\
\text { VST } \\
\text { Lentinan } \\
\text { Levamisole } \\
\text { DTC } \\
\text { RSB } \\
\text { WY-18251 } \\
\text { Control }\end{array}$ & $\begin{array}{l}20 / 25 \\
13 / 25 \\
13 / 25 \\
15 / 25 \\
14 / 25 \\
11 / 25 \\
13 / 25 \\
20 / 25\end{array}$ & $\begin{array}{l}80 \\
52 \\
52 \\
60 \\
56 \\
44 \\
52 \\
80\end{array}$ & $\begin{array}{l}\mathrm{N} \\
\mathrm{Y} \\
\mathrm{Y} \\
\mathrm{N} \\
\mathrm{N} \\
\mathrm{Y} \\
\mathrm{Y} \\
\mathrm{-}\end{array}$ \\
\hline \multicolumn{5}{|c|}{$\begin{array}{l}\text { 'Control groups were injected intraperitoneally with } \\
\text { modified Freund's incomplete adjuvant containing an } \\
\text { Aeromonas salmonicida bacterin } 27 \mathrm{~d} \text { prior to challenge } \\
\text { with } A \text {. salmonicida; all other groups received the indi- } \\
\text { cated immunostimulant and the bacterin } \\
{ }^{2} \mathrm{Y}=\text { significant at the } 0.05 \text { level; } N \text { = not significant at the } \\
0.05 \text { level by Fischer's exact test }\end{array}$} \\
\hline
\end{tabular}

challenged by immersion, a statistically significant improvement in survival over that of the group receiving bacterin alone was noted in fish administered bacterin combined with either VST, lentinan, DTC, RSB, or MFCA. In treatment groups challenged by the cohabitation method, a similar result was observed with the fish vaccinated with VST, lentinan, or RSB in combination with bacterin over that for controls receiving bacterin alone. Those fish receiving MFCA or DTC combined with antigen failed to show a significant improvement in survival over that of the respective control group.

Table 3 summarizes the effect of the candidate immunostimulants on the humoral immune response to the bacterin. Agglutinin levels were significantly elevated in all cases when bacterin was present. This occurred whether or not an immunostimulant was present. No significant elevation in agglutinin titre occurred as a result of combining an immunostimulant with the bacterin.

\section{DISCUSSION}

The screening trials identified 3 compounds with apparent immunostimulatory activity as measured in terms of survival following challenge: VitaStim-Taito, 
Lentinan, and killed, intact Renibacterium salmoninarum cells. When these immunostimulants were added to Aeromonas salmonicida bacterin, they resulted in a significantly increased level of protection against the furunculosis agent over that observed with bacterin alone. This effect occurred with each of the 2 challenge methods used. Three of the remaining 4 compounds (MFCA, DTC, WY-18,251) provided results that were inconsistent and one (levamisole) failed to show promise with any of the challenge methods used.

Levamisole has been demonstrated to be effective in elevating immunity in several mammalian studies, mainly where immune functions were considered to be impaired (Amery \& Horig 1984, Hennessy et al. 1987, Siwicki 1987). The drug clearly shows promise for use as an immunostimulant in fish on the basis of in vitro studies (Siwicki 1987, Anderson et al. 1989, Siwicki et al. 1989, 1990), and in 2 in vivo studies in salmonids, it enhanced resistance against 2 bacterial fish pathogens (Olivier et al. 1985a, Kajita et al. 1990). However, in the in vivo study by Olivier et al. (1985a), it yielded the least striking increase in Aeromonas salmonicida resistance among 3 immunostimulants tested. In addition, the immune response to levamisole can be suppressive or stimulatory, depending on the dose and the manner in which it is administered (Anderson et al. 1989). Such apparent complications in the application of levamisole indicate that more work is needed to determine the appropriate conditions for its use in fish. In view of the foregoing and because of the less than favorable in vivo results obtained in the present experiment with levamisole, we conclude that it would be more expedient to focus future studies on VST, lentinan, and RSB.

The inconsistent results obtained with MFCA also suggest that further studies with MFCA could be abandoned in favour of studies with the 3 more promising compounds listed above. The successful results obtained with MFCA by Olivier et al. (1985a) are difficult to reconcile with the inconsistent findings of the present study and it is only possible to speculate on an explanation for the inconsistency. It may well be that stimulation of the reticuloendothelial system by MFCA (Olivier et al. 1986) tends to be localized and that the challenge route must be the same as the vaccination route if maximum efficacy of the immunostimulant is to be obtained. In the present study the route of administration of the immunostimulant differed from that of the challenge route.

In the present experiment, enhanced protection was consistently obtained in groups receiving RSB in combination with Aeromonas salmonicida bacterin. This finding is consistent with observations made by Amend \& Johnson (1984). On the other hand, Turaga et al. (1987), using an in vitro assay (based on plaque forming cell counts) found that Renibacterium salmoninarum possessed immunosuppressive activity. Their findings, however, were obtained with the 'soluble proteins' produced by intact $R$. salmoninarum cells. The results of the present study with RSB are promising and the properties of the $R$. salmoninarum cells clearly warrant further investigation.

The consistent protection conferred by both VST and lentinan in our trials was not surprising because these agents are chemically closely related to each other (i.e. they are $\beta-1,3$ glucans with $\beta-1,6$ glycosidic side chains), they were known to possess anti-tumour activity (Aoki 1984, Sugawara et al. 1984), and they had been reported to produce resistance in carp Cyprinus carpio against Edwardsiella tarda, a bacterial fish pathogen (Yano et al. 1989). In addition, a similar compound derived from baker's yeast Saccharomyces cerevisiae has recently been shown to yield protection in Atlantic salmon Salmo salar against 3 bacterial fish diseases: vibriosis, coldwater vibriosis, and enteric redmouth disease (Robertson et al. 1990). Evidence suggests that these compounds act to enhance disease resistance by stimulating the macrophage component of the immune system (Sugawara et al. 1984, Yano et

Table 3. Oncorhynchus kisutch. Influence of the immunostimulants VitaStim-Taito, lentinan, and R. salmoninarum bacterin (RSB) on the agglutinin response to $\mathrm{A}$. salmonicida antigen $(\mathrm{Ag})^{1}$

\begin{tabular}{|c|c|c|c|c|}
\hline $\begin{array}{l}\text { Treatment } \\
\text { applied }\end{array}$ & $\begin{array}{l}\text { Mean } \\
\text { titre }^{2}\end{array}$ & $\begin{array}{l}\text { Sample } \\
\text { size }\end{array}$ & $\begin{array}{l}\text { Compared to antigen only } \\
\qquad \mathrm{p}<0.05^{3}\end{array}$ & $\begin{array}{c}\text { Compared to saline } \\
p<0.05^{3}\end{array}$ \\
\hline $\mathrm{VST}+\mathrm{Ag}$ & $79.3(12.8)$ & 11 & $\mathrm{~N}$ & $Y$ \\
\hline Lentinan + Ag & $29.3(7.4)$ & 9 & $\mathrm{~V}$ & $\mathrm{Y}$ \\
\hline $\mathrm{RSB}+\mathrm{Ag}$ & $136.0(47.4)$ & 10 & $N$ & Y \\
\hline Ag only & $50.7(15.5)$ & 9 & - & $\mathrm{Y}$ \\
\hline Saline control & $3.0(0.5)$ & 9 & $\mathrm{Y}$ & - \\
\hline \multicolumn{5}{|c|}{$\begin{array}{l}{ }^{1} \text { Coho salmon (average weight } 22.5 \mathrm{~g} \text { ) were vaccinated intraperitoneally with the indicated preparations and held for } 25 \mathrm{~d} \text { a } \\
13^{\circ} \mathrm{C} \pm 0.5 \mathrm{C}^{\circ} \\
2 \text { Bracketed values = standard error of mean } \\
3 \mathrm{Y}=\text { sianificant at the } 0.05 \text { level. } \mathrm{N}=\text { not significant at the } 005 \text { level by Student's t-test }\end{array}$} \\
\hline
\end{tabular}


al. 1989), a conclusion supported by earlier work conducted with another type of immunostimulant (Olivier et al. 1985a, 1986). However, as discussed below, the mechanism of action of the immunostimulants may be more complex when they function in the presence of a bacterin because, although when used alone they can induce protection equivalent to that obtained with bacterin alone (see Fig. 1 for results with VST, for example), the level of protection produced by combining them with bacterin is clearly enhanced (Table 2).

The increased protection against Aeromonas salmonicida challenge seen in the groups treated with $A$. salmonicida bacterin plus VST, lentinan, or RSB occurred despite the fact that no increases in the levels of A. salmonicida agglutinins had occurred at the time of challenge as a result of combining the bacterin with the immunostimulants (Table 3). Apparently, induced antiA. salmonicida agglutinins were not responsible for the observed increase in protection that occurred in these treatment groups. These data suggest that the immunostimulants did not enhance resistance to the pathogen by stimulating the B-cell (humoral antibody producing) component of the specific immune system. Instead, the enhanced protection may have been due to the stimulation of another component of this system (the T-cell component) which then interacted cooperatively with the reticuloendothelial system (the macrophages) to bring about the elimination of the pathogen. The cooperative involvement of $\mathrm{T}$-cells and macrophages in the process would not be surprising as VST, for example, is reported to be a T-cell activator in mammals (Sugawara et al. 1984). In addition, A. sal-

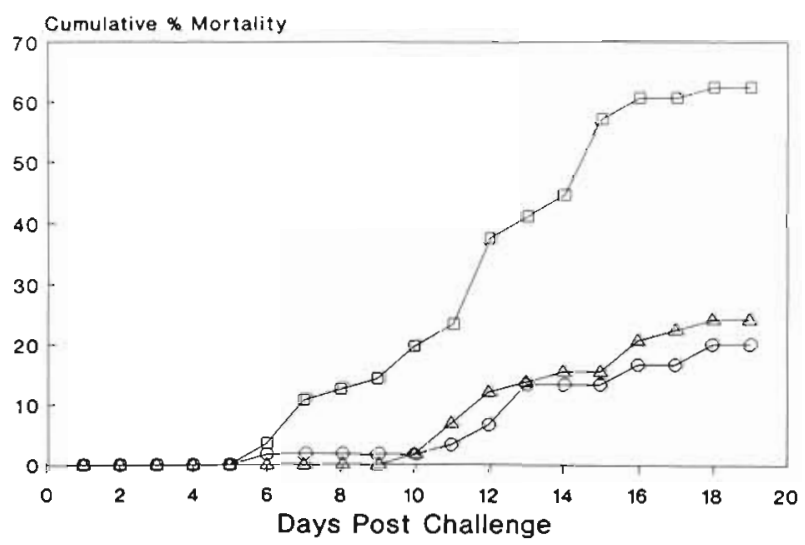

Fig. 1. Oncorhynchus kisutch. Mortalities in individuals treated by injection with saline, VST, or Aeromonas salmonicida bacterin, and challenged $24 \mathrm{~d}$ later with $\mathrm{A}$. salmonicida. Coho salmon $\left(60,5 \mathrm{~g}\right.$ fish group $\left.^{-1}\right)$ were injected intraperitoneally with $0.1 \mathrm{ml}$ of modified Freund's incomplete adjuvant containing saline ( $\bullet)$, crude VST $\left(20 \mathrm{mg} \mathrm{kg}^{-1}\right.$ fish) (A), or A. salmonicida bacterin (200 $\mathrm{mg} \mathrm{kg}^{-1}$ fish) (o). Fish were held in fresh water at $17^{\circ} \mathrm{C}$ and challenge was by a 15 min immersion in viable $A$. salmonicida cells $\left(5.3 \times 10^{5} \mathrm{ml}^{-1}\right)$ monicida-vaccinated rainbow trout produce soluble factors, reminiscent of the interleukins produced by $\mathrm{T}$ cells, that affect the activity of leucocytes (and presumably of macrophages) (Smith et al. 1980).

Recently, Michel et al. (1990) reported an interesting experiment in which enhanced resistance to furunculosis was obtained in rainbow trout in the absence of Aeromonas salmonicida-specific antibodies. The protection was induced by repeated injections of phosphate-buffered saline. The protection was thought to be due to the increased levels of polyspecific antibodies that resulted from the injections, and it was postulated that these antibodies exerted their protective effect by serving as opsonins which permitted increased phagocytosis of the pathogen by macrophages. We do not think that the immunostimulants used in our study functioned by inducing polyspecific antibodies because, based on their failure to enhance A. salmonicida agglutinin levels, they did not appear to function by stimulating antibody synthesis.

Future research on the 3 most promising immunostimulants identified in this study must first involve investigations to determine whether they can be administered by convenient and practical methods such as immersion or feeding. Research must also be conducted to establish the range of diseases with which the immunostimulants can be used to good effect. In connection with the foregoing, VST appears to be a particularly promising product. Unlike lentinan which is prepared from the fruiting body of an expensive mushroom (Lentinus edodes, a popular delicacy) and cannot be grown in fermentation culture, VST is derived from mycelia of the fungus Schizophyllum commune and is readily produced by fermentation culture. Further, unlike Renibacterium salmoninarum, grown with difficulty and therefore possibly expensive to mass produce, VST can be mass-produced at favourable cost. In addition, VST has already been chemically well defined, and, should it prove effective by feeding, its heat stability $\left(135^{\circ} \mathrm{C}\right.$; Yanaki et al. 1985) would permit it to withstand the high temperatures involved in incorporating it into steam-pelleted fish feeds.

Acknowledgements. The authors thank J. E. Ketcheson and Luigina Prosperi-Porta for expert technical assistance. This research was partially supported by grants to L.J.A. by the Natural Science Engineering Research Council of Canada and the Science Council of British Columbia.

\section{LITERATURE CITED}

Allison, A. C., Byers, N. E. (1986). An adjuvant formulation that selectively elicits the formation of antibodies of protective isotypes and of cell-mediated immunity. J. immun. Meth. 95: 157-168

Amend, D. F., Johnson, K. A. (1984). Evidence for lack of 
antigenic competition among various combinations of Vibrio anguillarum, Yersinia ruckeri, Aeromonas salmonicida, and Renibacterium salmoninarum bacterins when administered to salmonid fishes. J Fish Dis. 7: 293-299

Amery, W. K., Horig, C. (1984). Levamisole. In: Fenichel, R. L., Chirigos, M. A. (eds.) Immune modulation agents and their mechanisms. Marcel Dekker, New York, p. 383-408

Anderson, D. P., Siwicki, A, K., Dixon, O. W., Lizzio, E. F. (1989). Immunostimulation by levamisole in rainbow trout (Salmo gäirdneri) in vivo. In: Ahne, W., Kurstak, E. (eds.) Viruses of lower vertebrates. Springer-Verlag, Berlin, p. $469-478$

Aoki, T. (1984) Lentinan. In: Fenichel, R. L., Chirigos, M. A. (eds.) Immune modulation agents and their mechanisms. Marcel Dekker, New York, p. 63-77

Cipriano, R. C. (1982). Immunization of brook trout (Salvelinus fontinalis) against Aeromonas salmonicida: immunogenicity of virulent and avirulent isolates and protective ability of different antigens. Can. J. Fish. Aquat. Sci. 39: 218-221

Cipriano, R. C. (1983). Resistance of salmonids to Aeromonas salmonicida: relation between agglutinins and neutralizing activities. Trans. Am. Fish. Soc. 112: 95-99

Coon, J., Hunter, R. (1973). Selective induction of delayed hypersensitivity by a lipid conjugated protein antigen which is localized in thymus dependant lymphoid tissue. J. Immun. 110: 183-190

Davis, J. F., Hayasaka, S. S. (1984). The enhancement of resistance of the American eel, Anguilla rostrata Le Sever, to a pathogenic bacterium. Aeromonas hydrophilla, by an extract from the tunicate, Ecteinascidia turbinata. J. Fish Dis. 7 : $311-316$

Duff, D. C. B. (1942). The oral immunization of trout against Bacterium salmonicida. J. Immun. 44:87

Ellis, A. E. (1988). Current aspects of fish vaccination. Dis. aquat. Org. 4: $159-164$

Evelyn, T. P. T. (1977). An improved growth medium for the kidney disease bacterium and some notes on using the medium. Bull. off. Int. Epiz. 87(5-6): 511-513

Gregory, F. J. (1984). Thiazolobenzimidazole and thiazolobenzothiazole compounds as biological response modifiers. In: Fenichel, R. L., Chirigos, M. A. (eds.) Immune modulation agents and their mechanisms. Marcel Dekker, New York, p. $21-38$

Hamuro, J., Maeda, Y., Fukuoka, F., Chihara, G. (1974). Antitumour polysaccharides, lentinan and pachymaran as immunopotentiators. Mushroom Sci. 9: 477-487

Hennessy, K. J., Blecha, F., Pollman, S., Kluber, E. F. (1987) Isoprinosine and levamisole immunomodulation in artificially reared neonatal pigs. Am. J vet. Res. 48: 477-480

Kajita, Y., Sakai, M., Atsuta, S., Kobayashi, M. (1990). The immunomodulatory effects of levamisole on rainbow trout, Oncorhynchus mykiss. Fish Pathol 25: 93-98

Kitao, T., Yoshida, Y. (1986). Effect of an immunopotentiator on Aeromonas salmonicida infection in rainbow trout (Salmo gairdneri). Vet. Immun. Immunopathol. 12: $287-296$

Komatsu, N. (1974). Biological activities of schizophyllan. Mushroom Sci. 9: 867-869

Michel, C. (1979). Furunculosis of salmonids: vaccination attempts in rainbow trout (Salmo gairdnen) by formalinkilled germs. Ann. Rech. Vet. 10: 33-40

Michel, C., Gonzalez, R., Bonjour, E., Avrameas, S. (1990). A concurrent increasing of natural antibodies and enhance- ment of resistance to furunculosis in rainbow trout. Ann. Rech. Vet. 21: 211-218

Olivier, G., Evelyn, T P. T., Lallier, R. (1985a). Immunity to Aeromonas salmonicida in coho salmon (Oncorhynchus kisutch) induced by modified Freund's complete adjuvant: its non-specific nature and the probable role of macrophages in the phenomenon. Devl comp. Immun. 9: $419-432$

Olivier, G, Evelyn, T. P. T., Lallier, R. (1985b). Immunogenicity of vaccines from a virulent and an avirulent strain of Aeromonas salmonicida. J. Fish Dis. 8: 43-55

Olivier, G., Eaton, C. A., Campbell, N. (1986). Interaction between Aeromonas salmonicida and peritoneal macrophages of brook trout (Salvelinus fontinalis). Vet. Immun. Immunopathol. 12: 223-234

Panangala, V S., Haynes, T. B., Schultz, R. D., Mitra, A. (1986). Immunomodulation with killed Proprionibacterium acnes in guinea pigs simultaneously vaccinated with Brucella abortus strain 19. Vet. Immun. Immunopathol. 13 $71-84$

Parish, C. R. (1972). Preferential induction of cell-mediated immunity by chemical modification of sheep erythrocytes. Eur. J. Immun. 2: 143-151

Renoux, G., Renoux, M. (1984). Diethyldithiocarbamate (DTC): a biological augmenting agent specific for $T$ cells. In: Fenichel, R. L., Chirigos, M. A. (eds.) Immune modulation agents and their mechanisms. Marcel Dekker, New York, p. $7-20$

Robertsen, B., Rorstad, G., Engstad, R., Raa, J. (1990) Enhancement of non-specific disease resistance in Atlantic salmon, Salmo salar L., by a glucan from Saccharomyces cerevisiae cell walls. J. Fish Dis. 13: 391-400

Siwicki, A. (1987). Immunomodulating activity of levamisole in carp spawners Cyprinus carpo L. J. Fish Biol. 31 (Suppl A): $245-246$

Siwicki, A. K., Anderson, D. P., Dixon, O. W. (1989). Comparisons of nonspecific and specific immunomodulation by oxolinic acid, oxytetracycline and levamisole in salmonids. Vet. Immun. Immunopathol. 23: 195-200

Siwicki, A. K., Anderson, D. P., Dixon, O. W (1990). In vitro immunostimulation of rainbow trout (Oncorhynchus mykiss) spleen cells with levamisole. Devl comp. Immun. 14: $231-237$

Smith, P. D., McCarthy, D. H., Paterson, W. D. (1980). Further studies on furunculosis vaccination. In: Ahne, W. (ed.) Fish diseases, 3rd COPRAQ session, Springer-Verlag, Berlin, $p$ $114-119$

Sugawara, I., Lee, K. C., Wong, M. (1984). Schizophyllan (SPG)-treated macrophages and anti-tumour activities against syngeneic and allogeneic tumor cells. I. Characteristics of SPG-treated macrophages. Cancer Immun. Immunotherap. 16: 137-144

Turaga, P., Weins, G., Kaattari, S. L. (1987). Bacterial kidney disease: the potential role of soluble protein antigen(s). $J$ Fish Biol. 31 (Suppl. A): 191-194

Yanaki, T., Tabata, K., Kojima, T. (1985). Melting behaviour of a triple helical polysaccharide schizophyllan in aqueous solution. Carbohyd. Polymers 5: 275-283

Yano, T., Mangindaan, R. E. P., Matsuyama, H. (1989) Enhancement of the resistance of carp Cyprinus carpio to experimental Edwardsiella tarda infection, by some $\beta-1,3$ glucans. Nippon Suisan Gakk. 55:1815-1819

Zar, J. H. (1984). Biostatistical analysis. Prentice-Hall, Englewood Cliffs, New Jersey

Manuscript first received: May 3, 1991

Revised version accepted: August 14, 1991 